\title{
THE EFFECTIVENESS OF EDRAW MIND MAP APPLICATION IN TEACHING WRITING OF RECOUNT TEXT AT THE TENTH GRADE OF MAN 4 KEDIRI
}

\author{
Siti Pujiana
}

\begin{abstract}
The objectives of this study were (1) to describe the student's skill of recount text in an experimental class taught by using Edraw Mind Map, (2) to describe the students' skill of control class without being taught Edraw Mind Map, and (3) to investigate whether there is a significance in teaching writing skill of recount text between experimental and control class at tenth grade of MAN 4 Kediri. During the research quantitative approach of true experimental was used as the research design. This research used two classes which became experimental class (X Social Science Program 1) which was taught by using Edraw Mind Map Application and control class (X Natural Science Program 4) which was not taught by using Edraw Mind Map Application. The population was the first year students of MAN 4 in academic year of 2019/2020. Out of this population, 60 students were taken as sample. There were two classes, each of which consisted of 30 students. The data were collected by using writing test and questioners.
\end{abstract}

Key word: Edraw Mind Map application, recount text, teaching writing

\section{INTRODUCTION}

Writing is the way to express ideas in written form using letters, words, art or media, and it requires a mental process in order to express the ideas (Uusen, 2009). The material in the second grade based on the 2013 Curriculum Revision Specialization Program) the students are expected to be able to arrange spoken and written transactional interactional text, short and simple, involving personal text recount by paying attention to the correct social function, text structure, and language feature based on the context. This research chooses one material is personal recount text. According to Anderson in Dwi (2010), a recount is speaking or writing about past events or a piece of text that retells past events, usually in the order which they happened. The aim of the text retells the past event or to tell someone's experience in chronological order. This research use Edraw Mind Map as a learning media. Edraw Mind Map is a part of mind mapping application. Mind mapping itself means a creative note taking or note making technique in visualization and graphic (Buzan, 2008). It is different from the usual note making. In usual note making, people only list words, phrases or sentences from top to bottom or from left to right to pour their ideas, while in mind mapping, people use pictures, colors, and keywords.

This research has some objectives of study can be formulated as follow: (1) to describe the students' writing skill of recount text in an experimental class taught by using Edraw Mind Map Application at tenth grade of MAN 4 Kediri, (2) 
to describe the students' writing skill of recount text in a control class without taught by using Edraw Mind Map Application at tenth grade of MAN 4 Kediri, (3) to investigate whether there is a significant difference in teaching writing skill of recount text between experimental class and control class at tenth grade of MAN 4 Kediri

\section{METHODOLGY}

The research method used in this research was writing test. This research used two classes, they were experimental class and control class. All class give treatment and there used experimental design. Both classes were scored to determine the outcome. The scores were gotten from the test administered. The result of the test were used to investigate there is a significant difference in teaching writing skill of recount text.

This research was done at MAN 4 Kediri at Jl.Melati, no. 14, Badas, Kediri, East Java. The subject of this research was tenth grade of MAN 4 Kediri in the academic year 2018 - 2019. The amount students from both classes were 30 students. Social Program 1 class which was taught by using Edraw Mind Map Application and Natural Science Program 4 was not taught by using Edraw Mind Map Application but using discussion method. Total subject of this research is 60 students.

The instrument used in this research was a writing test. The test administered for experimental class and control class was the same. The test was given after teaching writing by using Edraw Mind Map Application or Discussion method is done. The students were asked to write a recount text in the title "Past Experience" used 10 sentences in every paragraphs consisting of orientation, events, and re-orientation. Time allocation for doing test was 60 minutes. Their writing would be score based on some aspect, they are; content 30\%, organization $20 \%$, Grammar $20 \%$, vocabulary $15 \%$, and Mechanic $15 \%$. This research done to find out the instrument quality, they were; its validity, reliability and normality.

This research typically involved two classes. Those class were given the same treatment. Experimental class (X Social Science Program 1) was given new treatment using Edraw Mind Map. Meanwhile, the control class (X Natural Science Program 4) will give another method by using discussion and there are six meetings and one meeting for doing test

In the first meeting the researcher explains about the application usage and the student learn how to make it. Then the researcher divide the student in pairs to make an outline like the example in LCD Projector. After that, the student collecting their project. In this section, the students it is so excited and so happy because was gotten the new experience in learning. In second meeting the researcher explains the material about recount text (definition, the function, generic structure, and language feature). Then the researcher ask the students to make a small group and given the time for reading their book about the material and must be reviewing what they had gotten and go forward for presentation. In this section, the students was gotten more knowledge about recount text.

In the third meeting, the researcher gives the text on LCD Projector to discuss gather about the vocabulary or language use and the task for the students 
to make outline about holiday by using Edraw Mind Map Application. Then the researcher ask the student to presentation about their work in front of class. In this section, the students can develop their vocabulary with their friends, can share their ideas to make an outline with each other, and can construct the good sentence.

In the fourth meeting, the researcher with the student's reviews about their task based on language use and if there are false, the students revise their words. The students with their group analyze the text from teacher guidance. In this section, the students can resolve their error in text.

In the fifth meeting, the researcher gives the task about holiday again and the students with their groups make an outline by using Edraw Mind Map Application and develop it to be good paragraph. After that, the student collecting their project. In this section, the task of writing students are better than third meeting. They can make organize sentence to be good.

The last meeting, the researcher gives the students test as long as 60 minutes. It was administrated to get the students' score. The criteria of test consist about; 1) content, 2) organization, 3) grammar, 4) vocabulary, and 5) mechanic.

The researcher using the T-test. The researcher tries to find the difference of writing recount text after being taught using Mind Mapping through Edraw Mind Map by using Independent T - Test in a way (1) Make code 1 for method A, and 2 for method B (2) Open spss, open the view variable, select the second values section, fill in 1: use what class / method / strategy / technique you are; 2: what method / class (3) Change mensure with nominal (4) Rename part of one result column, column two Class (5) Open data view, enter the total value of each child's class with a different number. After finding the t-test result or t-test value, the next step is interpreting it. If the significance is the same as or is lower than $5 \%$, the difference of both classes is found and Edraw Mind Map Application is Effective.

\section{DATA ANALYSIS}

To measure the result of the test instrument, this research using validity, reliability, normality and independent sample test. The validity of instrument was using content validity and construct validity. The test was said have content validity if its contents constitute a representative sample of language skills, structure, etc., being tested. Beside that the content of instrument has to relevant with the purpose of the test. In this case, the content validity should refer to Basic Competence in 2013 curriculum, the students are expected to be able to arrange spoken and written transactional interactional text, short and simple, involving personal text recount by paying attention to the correct social function, text structure, and language feature based on the context. Besides, they should be able to develop recount text in the form or work bibliographical.

Construct validity focuses on the kind of test that is used to measure the ability. According to Setiyadi in Brown (2007), construct validity is used to measure perception, language behavior, motivation, even the language ability.

The reliability of instrument result could be seen at the value of Cronbach's Alpha was 0.692. The instrument reliability criteria is in the range $0,61<\mathrm{r} \leq 0,80$. Based on the result it can be conclude the reliability is in the high criteria. 
The normality of instrument was shown in histogram. If the histogram had a peak, it meant the data could be included in normal distribution.

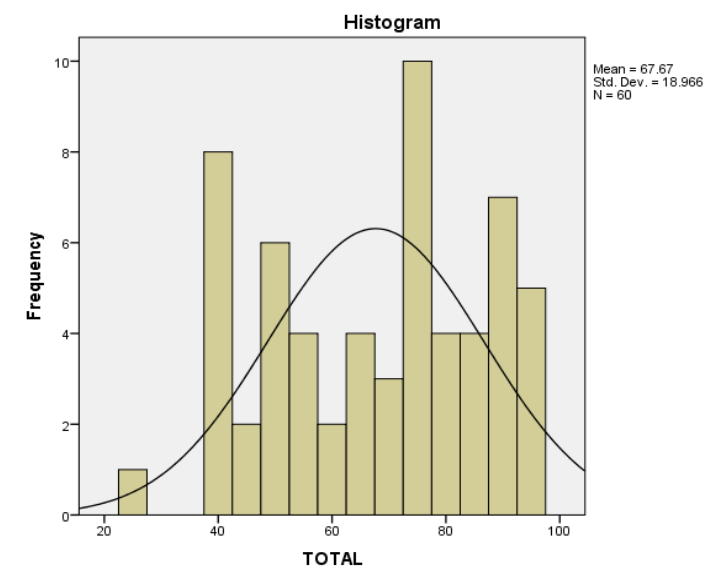

Based on the figure 3.1 , it can be concluded that the instrument distributed normally. It was proven by the peak that appeared in the diagram. The result of test was measuring by using SPSS version 23. The result of the test shown below:

\section{Group Statistics}

\begin{tabular}{|r|l|l|l|l|}
\hline Class & $\mathrm{N}$ & $\begin{array}{l}\text { Mean } \\
(\mathrm{M})\end{array}$ & $\begin{array}{l}\text { Std. } \\
\text { Deviation } \\
(\mathrm{SD})\end{array}$ & $\begin{array}{l}\text { Std. } \\
\text { Error } \\
\text { Mean }\end{array}$ \\
\hline $\begin{array}{l}\text { Edraw } \\
\text { Mind Map }\end{array}$ & 30 & 75.50 & 20.229 & 3.693 \\
SCORE Discussion & 30 & 59.83 & 13.988 & 2.554 \\
\hline
\end{tabular}

The table reveals a difference in mean value between the Experimental class $(M=75.50, S D=20.229)$ and the control class $(M=59.83, S D=13.988)$. The test achievement test between experimental and control group are different, the researcher conduct t-test. Based on significant difference between two class if sig. (2-tailed) value is the same or lower than 0.005 , it can be concluded that there is significant difference between the average learning outcomes of experimental class and control class. From table 4.8, it can be seen that "Mean Difference" is 15.667. This value shows the difference in the average student learning outcomes between experimental class and control class also the difference is 6.678 until 24.655 (95\% Confidence Interval of The Difference Lower Upper). $\mathrm{T}_{\mathrm{obs}}=3.489$ means that the average value of students in experimental class is lower than the average value in the control class, so it can be conclude that $\mathrm{H}_{\mathrm{o}}$ is rejected and $\mathrm{H}_{\mathrm{a}}$ is accepted. 


\section{CONCLUSION}

From the result of the research, it can be concluded that; 1) the students' writing skill of recount text in experimental class being taught by Edraw Mind Map Application at tenth grade of MAN 4 Kediri is good category with the mean score 75.50. 2) the students' writing skill of recount text in control class without being taught by Edraw Mind Map Application at tenth grade of MAN 4 Kediri is fair category with the mean score 59.83. 3). There is significant difference in teaching writing skill of recount text between the experimental and control class at tenth grade of MAN 4 Kediri. It is shown from the results of the data analysis descriptive that mean score of experimental class was higher than the control classes mean. The value of experimental class was 75.50 with 'good' category while the control class was 59.83 with 'fair' category. It is also proven by the result of independent-samples t-test by SPSS 23 version that t-test which value 3.489 and sig. (2-tailed).

\section{REFERENCE}

Anderson M., \& Anderson, K. 1997. Text types in English. South Yara: Macmillan Education Australia.

Brown. 2007. Teaching By Principles: An Interactive Approach to Language Pedagogy. $2^{\text {nd }}$ Ed. San Fransisco: Longman

Buzan, T. 2008. Buku Pintar Untuk Anak agar Anak Mudah Menghafal dan Berkonsentrasi. Jakarta: PT Gramedia Pustaka.

Uusen, A. (2009). Changing Teachers' Attitude towards Writing, Teaching of Writing and Assessment of Writing. Retrieved from adobe acrobat reader [2009-10.pdf] accessed on February 10st, 2019. 